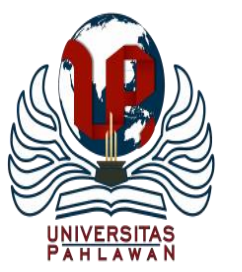

Edukatif : Jurnal Ilmu Pendidikan Volume 2 Nomor 2 Tahun 2020 Halm 134-143

EDUKATIF: JURNAL ILMU PENDIDIKAN

Research \& Learning in Education

https:/ledukatif.org/index.php/edukatif/index

\title{
Kebijakan Standar Proses Di Sekolah Dasar
}

\author{
Lisa Syupriyanti ${ }^{1}$, Sufyarma Marsidin ${ }^{2}$, Ahmad Sabandi $^{3}$ \\ Universitas Negeri Padang, Sumatera Barat, Indonesia ${ }^{1,2,3}$ \\ E-mail : lisavkr@gmail.com ${ }^{1} \underline{\text { sufyarma1954@gmail.com }}{ }^{2}$ sabandi@fip.unp.ac.id ${ }^{3}$
}

\begin{abstract}
Abstrak
Tulisan ini membahas dan menganalisis kebijakan standar proses di sekolah dasar. Seperti yang diketahui, untuk mewujudkan tujuan pendidikan yang diharapkan, maka sistem pembelajaran harus mengarah pada standar proses. Standar proses yaitu standar nasional pendidikan yang berhubungan dngan proses pelaksanan pembelajaran dalam pendidikan untuk tercapainya standar kompetensi lulusan. Berdasarkan penelitian melalui kajian pustaka yang dilakukan, maka diperoleh beberapa kebijakan yang harus dilakukan dalam pelaksanaan standar proses. Untuk itu manfaat dari penelitian ini ialah upaya yang dilakukan guru dalam menerapkan standar proses yang telah ditentukan dari satuan pendidikan agar terciptanya pembelajaran yang bermakna.
\end{abstract}

Kata kunci : kebijakan, standar proses, sekolah dasar

\begin{abstract}
This paper discusses and analyzes the default process policy in elementary school. As is known, to realize the desired educational purpose, then the learning system must lead to a standard process. Process standards are the national standard of education related to the implementation of learning in education to achieving the competence standards of graduates. Based on research through library studies done, some policies should be made in the standard implementation of the process. For that reason the benefits of this study are the efforts teachers make in applying predetermined process standards to create meaningful learning.
\end{abstract}

Keywords : policy, default process, primary school

Copyright (c) 2020 Lisa Syupriyanti, Suryarma Marsidin, Ahmad Sabandi

$\triangle$ Corresponding author :

Address : Padang, Sumatera Barat

ISSN 2656-8071 (Media Cetak)

Email : $\underline{\text { lisavkr@gmail.com }}$

ISSN 2656-8063 (Media Online)

Phone : 085263867726

DOI: 10.31004/edukatif.v2i2.116

Edukatif : Jurnal Ilmu Pendidikan Vol 2 No 2 Tahun 2020 p-ISSN 2656-8063 e-ISSN 2656-8071 


\section{PENDAHULUAN}

UU No 20 Tahun 2003 tentang Sistem Penddikan Nasional, Pasala 1 ayat 1 menyatakan bahwa pendidikan merupakan suatu usaha yang terencana dalam mewujudkan proces belajar mengajar dan suasana belajar yang kondusif agar siswa dapat mengembangkan potensidirinya.

Menurut PP No 19 Tahun 2005 mengenai Standar Nasional Pendidikan salah satu standar yang harus dikembangkan ialah standar proses. Standar proses merupakan kriteria acuan tentang dalam pelaksanaan pembelajaran tingkat satuan pendidikan untuk tercapainya standar kompetensi kelulusan. Standar tersebut bertujuan untuk mengoptimalkan pencapaian output sesuai dengan standar kompetensi kelulusan dengan melalui evaluasi berdasarkan standar penilaian pendidikan.

Standar proses mempunyai kriteria minimal dalam proses pembelajaran pada tingkat satuan pendidikan dasar maupun menengah yang ada pada hukum NKRI. Standar proses berlaku pada tiap jenjang pendidikan dasar maupun menengah pada jalur formal, baik sistem paket dan sistem kredit semester. Pengembangan standar proses untuk mengarah pada standar kompetnsi kelulusan dan standar isi yang sudah ditentukan dan disesuaikan dengan ketentuann da;am PP No 19 Tahun 2005 tentang Standar Nasional Pendidikan sebagaimna yang sudah diganti dengan PP No 32 Thn 2013.

Standar proses yang dilakukan melalui perencanan proces pembelajaran, pelaksanan proses pembelajaran, penilaian hasil pembelajaran dan pengawasan proses pembelajaran agar proses pembelajaran dapat terlaksana secara efektif dan efisien.
Dalam proses pembelajaran tingkat satuan pendidikan dapat dilaksanakan secara interaktif, menyenangkan, inspiratif, dan mendorong siswa untuk dapat aktif serta memberikan tempat yang cukup untuk kreatif dan kemauan sesuai dengan minat, bakat, perkembangan fisik dan psikis dari siswa. Maka dari itu tiap tingkat satuan pendidikan dapat membuat perencanan pembelajaran, pelaksanaan proses pembelajaran serta evaluasi yang dilakukan dalam proses pembelajaran untuk meningkatkan efektifitas tercapainya kompentesi kelulusan.

\section{METODE PENELITIAN}

Metode yang diterapkan pada kajian ini ialah dengan library research. Library research yaitu serangkaian kgiatan yang berhubungan dengan mengumpulkan data kepustakaan, mencatat, membaca dan mengolah bahan tersebut. Penelitian ini disebut penelitian pustaka karena data-data atau bahan yang digunakan dalam menyelesaikan sebuah penelitian berasal dari pustaka berupa buku, kamus, dokumen ensiklopedi, jurnal, majalah dan sebagainya (Harahap, 2014).

Oleh karena itu, pengumpulaan data dalam penelitian dilakukan dengan menelaah atau mengeksplorasi beberapa buku, jurnal, dan dokumen cetak maupun elektroniik serta sumber data atau informasi lainya yang sesuai dengan penelitian yang dilakukan.

\section{HASIL DAN PEMBAHASAN PENELITIAN}

\section{Pengertian Standar Proses Dan Pembelajaran}

Standar dapat dikatakan sebagai suatu ukuran tertentu yang digunakan sebagai acuan 
yang baku. Sedangkan proses merupakan perubahan peristiwa pada suatu perkembangan. Suatu hal mengalami perkembangan termasuk dalam hal pembelajaran, sehingga proses yang dikatakan merupakan hal yang berhubung dengan perkembangan dari proses pembelajaran tersebut. Selain itu, pembelajaran ialah proses belajar agar seseorang melakukan kegiatan belajar (KBBI).

Menurut UU No 20 Tahun 2003 tentang System Pendidikan Nasional menyebutkan pembelajaran yaitu suatu proses interaksi guru dengan siswa serta sumber belajar pada lingkungan belajar. Sedangkan pembelajaran ialah usaha pendidikan yang sengaja dilakukan agar tujuan yang ditetapkan sebelum proses pembelajaran dilakukan serta pelaksanaanya dapat terkendali (Miarso).

Dari pendapat ahli tersebut, kesimpulannya bahwa pembelajaran ialah suatu aktifitas yang dilakukan pendidik dalam membelajarkan peserta didik dalam lingkungan belajar dengan tujuan terjadinya perubahan tingkah laku. Oleh karena itu, pembelajaran merupakan suatu proses tertentu yang mempunyai unsur yang saling terikat dan terkait.

Unsur itu merupakan pendidik, peserta didik, tujuan pembelajaran, kurikulum, strategi pembelajaran, media pembelajaran dan evaluasi. Diantara komponen tersebut mempunyai hubungan yang terdapat sebagai pembentuk suatu kegiatan proses pembelajaran.

Proses pembelajaran ialah semua kegiatan yang telah direncanakan untuk membelajarkan siswa. Pada tingkat satuan pendidikan, proses pembelajaran dilaksanakan secara interaktif, menyenangkan, inspiratif dan motivasi siswa untuk ikut berperan aktif sesuai dengan minat, bakat, perkembangan fisik dan psikis dari diri siswa tersebut.

\section{Karakteristik Pembelajaran Yang Sesuai Dengan Standar Pendidikan}

Karakteristik pembelajaran pada tiap tingkat satuan pendidikan berkaitan dengan standar kompetensi kelulusan dan standar isi. Standar kompetensi kelulusan memberikan kerangka konseptual tentang sasaran dari pembelajaran yang hendak dicapai, sedangkan standar isi memberikan kerangka konseptual tentang kegiatan belajar mengajar yang turunan dari kompetensi dan materi.

Berdasarkan standar kompetensi kelulusan, sasaran dari pembelajaran yang mencakup dari perkembangan ranah sikap, pengetahuan dan keterampilan yang dielaborasi untuk tiap satuan pendidikan. Ranah sikap dapat diperoleh dengan akifitas seperti menerima, menjalankan, menghargai, menghayati, dan mengamalkan. Ranah pengetahuan dapat diperoleh dengan aktifitas seperti mengingat, memahami, menerapkan, menganalisis, mengevaluasi dan mencipta. Sedangkan untuk ranah keterampilan dapat aktivitas dengan kegiatan seperti mengamati, menannya, mencoba, menalar, menyaji dan mencipta.

Perbedaan karkteristik kompetensi yang diperoleh ikut serta dalam mempengaruhi karakteristik standar proses. Untuk memperkuat pendekatan ilmiah, tematik dan tematik terpadu perlu untuk diterapkannya pembelajaran berbasis inquiry/discovery dan project basedlearning yang dapat mendorong kemampuan siswa untuk 
menghasilkan suatu karya.

Karateristik proses pembelajaran disesuaikan dengan karakteristik kompetensi. Pada tingkat SD/MI pembelajaran tematik terpadu disesuaikan dengan tingkat perkembangan dari siswa. Pada tingkat SMP/MTs pembelajaran tematik terpadu sesuai dengan karakteristik kompetensi yang mengenalkan muatan pelajaran dengan memperhatikan tematik terpadu pada IPA dan IPS. Sedangkan karakteristik proses pembelajaran pada tingkat SMA/MA secara keseluruhan berbasis muatan pelajaran walaupun pendekatan tematik tetap ada. Standar proses yang dilakukan pada SDLB, SMPLB dan SMALB diperuntukan bagi berkebutuhan khusus yang intelegensinya normal.

UU No 20 Tahun 2003 mengenai Sistem Pendidikan Nasional sudah menerapkan taksonomi dalam bentuk rumusann sikap, pengetahuan dan keterampilan. Proses pembelajaran dapat diarahkan pada perkembangan ketiga ranah tersebut secara keseluruhan yang artinya perkembangan ranah tersebut tidak dapat dipisahkan satu sama lainnya. Dengan demikian proses pembelajaran secara utuh dapat melahirkan kualitas individu yang mencermikan keutuhan dari penguatan sikap, pengetahuan dan keterampilan tersebut.

\section{Perencanaan, Pelaksanaan Dan Penilaian Yang}

Dilakukan Dalam Proses Pembelajaran

\section{Perencanan Dalam Proses Pembeljaran}

Perencanan merupakan kata rencana yang maksudnya ialah pengambilan keputusan tentang apa yang harus dilakukan agar tercapainya suatu tujuan. Untuk itu, perencanan harus mulai dari penetapan tujuan yang hendak dicapai setelah itu menetapkan langkah yang akan dilakukan untuk tercapainya tujuan tersebut. Perencanaan ialah suatu cara yang dapat membuat kegiatan berlangsung dengan baik serta berbagai langkah yang dapat berguna untuk memperkecil kesenjangan yang terjadi sehingga kegiatan tersebut dapat tercapai tujuannya (Hamzah B Uno).

Dalam pembelajaran, perencanaan dapat dikatakan sebagai proses dari penyusunan materi, penggunaan media, metode dan pendekatan pembelajaran serta evaluasi dalam waktu yang dilakukan pada masa tertentu untuk tercapainya tujuan yang diharapkan. Perencanan proses pembelajaran yang baik akan berdampak pada proses pembelajaran yang baik juga. Oleh karena itu, dalam penyusunan perencanan membutuhkan pedoman yang akan membuat rencana proses pembelajaran berfungsi sebagaimana seharusnya. Perencanan proses pembelajaran seperti program penyusunan program tahunan, program semester, alokasi waktu, silabus dan RPP (Wina Sanjaya).

Perencanan pembelajaran yang dibuat dalam bentuk silabus dan RPP mengarah pada standar isi. Perencanan pembelajaran seperti penyusunan RPP dan persiapan sumber belajar, media, perangkat penilaian serta skenario pembelajaran. Susunan silabus dan RPP dapat disesuaikan dengan pendekatan pembelajaran yang akan dipakai.

a. Silabus

Silabus adalah pedoman susunan 
kerangka pembelajaran pada tiap kajian mata pelajaran. Pada silabus berisi : 1) identitas muatan pelajaran (khusus SMP dan SMA), 2) identitas sekolah, 3) kompetensi inti, 4) kompetensi dasar, 5) materi pokok, 6) kegiatan pembelajaran, 7) penilaian, 8) alokasi waktu, 9) sumber belajar. Pengembangan silabus disesuaikan dengan standar kompetensi kelulusan dan standarisi pada tingkat satuan pendidikan dasar maupun menengah yang sesuai dengan pola pembelajaran pada tiap tahun ajaran tertentu. Silabus berfungsi sebagai pedoman dalam mengembangkan RPP.

b. Rencana Pelaksanaan Pembelajaran

RPP ialah rancangan kegiatan pembelajarn tatap muka untuk sekali pertemuan maupun lebih. RPP merupakan pengembangan dari silabus untuk mengarahkan kegiatan pembelajaran dalam $\mathrm{KD}$ yang ingin dicapai. Setiap pendidik pada tingkat satuan pendidikan wajib untuk membuat RPP secara lengkp dan sistematis agar pembelajaran dapat berlangsung secara interaktif, menyenangkan, inspiratif, dan mendorong siswa untuk dapat aktif serta memberikan tempat yang cukup untuk berkreatif dan kemauan sesuai dengan minat, bakat, prkembangan fisik dan psikis dari siswa. RPP disusun berdasarkan $\mathrm{KD}$ atau subtema yang dilakukan dalam satu kali pertemuan atau lebih.

Adapun komponen RPP ialah :
1) Identitas sekolah

2) Identitas mata pelajaran/tema/subtema

3) Kelas/semester

4) Materi pokok

5) Alokasi waktu

6) Tujuan pembelajaran

7) KD dan Indikator

8) Materi pemblajaran

9) Metode pemblajaran

10) Mediia pmbelajaran

11) Sumber blajar

12) Langkah-langkah pemblajaran

13) Penilaian hasilpembelajaran

Dalam menyusun sebuah RPP perlu melihat beberapa prinsip seperti:

1) Perbedaan individu siswa

2) Peserta didik ikut untuk berpartisipasi aktif

3) Berpusat pada siswa

4) Pengembangan budaya dalam baca dan tulis

5) Pemberian umpan balik dan tindak lanjut RPP

6) Penekanan pada keterpaduan dan keterkaitan antara KD, materi, kegiatan pembelajaran, indikator, evaluasi dan sumber belajar dalam satu kesatuan keutuhan pengalaman belajar

7) Mengakomodasi pembelajaran tematik terpadu, keterpaduan antar muatan pelajaran, lintas aspek belajar dan keragaman budaya

8) Penerapn TIK scara sistematis, terintegrasi dan efektif ssuai dengan 
situasi dankondisi

\section{Pelaksanaan Proses Pembelajaran}

Pelaksanan proses pembelajaran ialah unsur yang paling penting dalam mewujudkan kualitas output pendidikan. Oleh sebab itu, dalam pelaksanan proses pembelajaran harus dilakukan secara tepat, ideal dan proposional. Dengan demikian, pendidik dapat mengimpelementasikan teori yang berkaitan dengan teori pembelajaran ke dalam pembelajaran yang realitas sebenarnya.

Pelaksanaan pembelajaran ialah pelaksanaan strategi yang sudah disusun untuk tujuan pembelajaran yang hendak dicapai. Berdasarkan Permendikbud No 65 Tahun 2013 bahwa dalam pelaksanan proses pembelajarn perlu syarat dalam melaksanakan proses pembelajaran itu sendiri yang kemudian dilanjutkan dengan pelaksanaan pembelajaran (Roy R Lefrancois yang dikutip dari Dimyati Mahmud). Syarat pelaksanaan proses pembelajaran itu ialah :

a. Persyaratan Pelaksanaan Proses Pembelajaran

1) Alokasi waktu

a) Tingkat SD/MI ialah 35 menit

b) Tingkat SMP/MTs ialah 40 menit

c) Tingkat SMA/MA ialah 45 menit

d) Tingkat SMK/MAK ialah 45 menit

2) Buku teks pelajaran

3) Pengelolaan kelas

a) Guru perlu melakukan penyesuaian untuk pengaturan posisi tempat dduk siswa

b) Volume dan intonasi suara guru dapat didengar dengan baik dan jelas oleh siswa

c) Guru mengunakan kata-kata yang baik, sopan, santun, dan mudah dimengerti oleh siswa

d) Guru menyesuiakan materi pelajaran yang diberikan dengan kemampuan dan kecepatan dari siswa

e) Guru menciptakan ketertiban, keselamatan dan kenyamanan serta kedisplinan dalam proses pembelajaran berlangsung

f) Guru memberikan penguatan dan umpan balik terhadap respon dan hasil belajar siswa

g) Guru memotivasi dan menghargai siswa untuk bertanya serta mengemukakan pendapat

h) Guru berpakaian yang sopan, bersih dan rapi

i) Pada tiap awal tahun ajaran/semester, guru hendaknya menjelaskan silabus pada siswa

j) Guru memulai dan mengakhiri proses pembelajaran sesuai dengan alokasi waktu yang telah dirancang

b. Pelaksanaan Pembelajaran

Pelaksanaan pembelajaran ialah implementasi dari RPP seperti kegiatan awal, kegiatan inti dan kegiatan akhir.

1) Kegiatan Awal 
Dalam kegiatan awal hal yang harus

dilakukan guru ialah:

a) Mengkondisikan

kelas, mempersiapkan siswa baik secara fisik maupun psikis dalam mengikuti proses pembelajaran

b) Memberikan motivasi belajar kepada siswa

c) Melakukan tanya jawab yang dikaitkan dengan pengetahuan sebelumnya dan materi yang hendak dipelajari

d) Menjelaskan tujuan pembelajaran atau KD yang hendak dicapai

e) Menyampaikan cakupan materi dan penjelasan uraian kegiatan yang sesuai dengan silabus

2) Kegiatan Inti

Kegiatan inti menggunakan metode, model, media pembelajaran dan sumber belajar yang sesuai dengan karateristik dari siswa dan muatan pe;ajaran. Pemilihan pendekatann tematik atau tematik terpadu atau sainstifik atau discovery atau inquiri serta project based learning disesuiakan dengan karateristik komptensi dan jenjang pendidikan.

a) Sikap

Sesuai dengan karateristik sikap, maka salah satu cara yang dipilih ialah proses afeks mulai dari menerima, menjalankan, menghargai, menghayati hingga menggamalkan. Semua aktifitas pembelajaran berorientasi pada tahapan kompetensi yang dapat mendorong siswa untuk melakukan kegiatan tersebut.

b) Pengetahuan

Pengetahuaan diperoleh dengan aktifitas menggetahui, memahami, menerapkan, menganalisis, mengevaluasi dan mencipta. Karateristik kegiatan belajar dalam ranah pengetahuan memiliki perbedaan dan persamaan dengan kegiatan belajar dalam ranah keterampilan. Untuk memperkuat pendekatan sainstifik, tematik terpadu dan tematik sangat diharapkan untuk dapat menerapkan pembelajaran berbasis inquiry/diiscovery dan project basedlearning.

c) Keterampilan

Keterampilan dapat diperoleh dengan aktifitas menggamati, menanya, mencoba, menalar, menyaji dan mencipta. Segala isi materi topik atau subtopik muatan pelajaran yang diturunkan dari keterampilan harus mendorong peserta didik untuk melakukan suatu pengamatan hingga mencipta untuk mewujudkan keterampilan tersebut harus melakukan pembelajaran yang diterapkan melalui metode belajar berbasis inquiry/discovery dan project basedlearning. 
3) Kegiatan Akhir

Dalam kegiatan akhir, pendidik bersama peserta didik melakukan refleksi untuk mengevaluasi yaitu :

a) Seluruh rangkian kegiatan pembelajaran dan hasil yang diperoleh untuk selanjutnya dapat menemukan manfaat pembelajaran

b) Memberikan umpan balik pada proses dan hasil pembelajaran

c) Melakukan kegiatan tindak lanjut dalam bentuk tugas secara pribadi dan kelompok

d) Menginformasikan rencana kegiatan pembelajaran pada minggu selanjutnya

\section{Penilaian Proses Pembelajaran}

Penilaian ialah proses memberikan dan menentukan nilai pada suatu objek tertentu berdasarkan suatu kriteria tertentu. Dalam proses pembelajaran, penilaian mempunyai peran yang penting seperti untuk mengetahui tercapai atau tidaknya proses pembe;ajaran yang telah dilakukan. Penilaian ialah suatu proses yang terurut mulai dari pengumpulan, analisis, interpretasi informasi data untuk menentukan sejauh mana siswa sudah mencapai tujuan pembelajaran. Penilaian pada umumnya dilakukan untuk memberikan pertimbangan dan nilai berdasarkan acuan tertentu. Hasil yang diperoleh dari penilaian inilah nanti dibentuk dalam hasi lbelajar (Gronlund yang dikutip dari Zainal Arifin).

Penilaiann hasil belajar merupakan proses memberikan nilai terhadap hasil yang telah didapat oleh peserta didik dengan memenuhi acuan tertentu. Oleh karena itu, maka penilaian hasil belajar mempunyai beberapa fungsi seperti :

a. Alat untuk mengetahui perkembangan dan kemajuan serta keberhasilan peserta didik setelah mengikuti proses belajar mengajar selama kurun waktu tertentu

b. Alat untuk mengetahui tingkat keberhasillan suatu program pembelajaran

c. Alat untuk keperluan BK

d. Alat untuk keperluan pengembangan dan perbaikan

Berdasarkan Permendikbud No 65 Tahun 2013 bahwa penilaian proses pembelajaran harus menggunakan pendekatan penilaian yang autentik dengan menilai kesiapan siswa, proses dan hasi; belajar secara keseluruhan. Keterpaduaan penilaian dari ketiga ranah tersebut akan dapat mengambarkan kapasitas, gaya dan perolehan hasil belajar peserta didik untuk menghasilkan dampak instruksional dan pegiring pada pembelajaran.

Hasil penilaian autentik ini nanti dapat digunakan oleh guru untuk merencanakan program remedi, pengayan dan pelayanan konseling. Selain itu, hasil penilaian autentik ini dapat digunakan sebagai bahan untuk memperbaiki proses pembelajaran yang sesuai dengan Standar Penilaian Penddikan. Penilaian proses pembelajaran dilakukan saat prosess pembelajaran berlangsung dengan menggunakan angket, pengamatan, catatan anekdot maupun refleksi. 
Pengawasan Yang Dilakukan Dalam Proses

\section{Pembelajaran}

Pengawasan proses pembelajaran yang dilakukan melalui kegiatan pemantauan, supervisi, evaluasii, pelaporan dan tindak lanjut secara berkala maupun berkelanjutan. Pengawasan proses pembelajaran dapat dilakukan oleh kepala satuan pendidikan setingkat dan pengawas.

1. Prinsip Pengawasan

Pengawasan dilakukan secara objektif dan transparan yang berguna untuk meningkatan mutu secara berkelanjutan dan menetapkan peringkat akreditasi

2. Sistem dan Entitas Pengawasan

Sistem pengawasan internal yang dilakukan oleh kepala sekolah, pengawas dan dinas pendidikan serta LPMP.

a. Kepala sekolah, pengawas dan LPMP melakukan pengawasan dalam rangka untuk peningkatan mutu

b. Kepala sekolah dan pengawas melakukan pengawasan dalam bentuk supervisi akademik dan manajerial

c. Pengawasan yang dilakukan LPMP dalam bentuk evaluasi diri sekolah

3. Proses Pengawasan

a. Pemantauan

Pemantauan proses pembelajaran dilakukan dengan tahap perencanan, pelaksanan dan penilaian hasil pembelajaran. Pemantauan dilakukan dengan diskusi kelompok terfokus, observasi, catatan, rekaman, wawancara dan dokumentassi

b. Supervisi

Supervisi prosess pembelajaran dilakukan dengan tahap perencanan, pelaksanaan dan penilaian hasil pembelajaran yang dilakukan dengan memberikan contoh, konsultasi, diskusi dan pelatihan

c. Pelaporan

Hasil kegiatan pemantauan, supervisi dan evaluasi proses pembelajaran disusun dalam bentuk laporan untuk ditindak lanjut pengembangan keprofesional pendidik secara berkelanjutan

d. Tindak Lanjut

Tindak lanjut hasil pengawasan dilakukan dalam bentuk:

1) Penguatan dan penghargaan kepada guru yng telah menunjukan kinerja yang memenuhi syarat atau melampaui standar

2) Pemberian kesempatan kepada guru untuk mengikuti program pengembangaan keprofesional berkelanjutan

Disinilah perbedaan antara peraturan PP No 19 Tahun 2005 yang lama dengan Permendikbud No 65 Tahun 2013 ialah adanya fungsi supervsi sebagai pengawas jalannya proses kebijakan pembelajaran di sekolah maupun madrrasah sehingga dapat diharapkan untuk lebih mengoptimalkan pencapaian standar proces yang diharapkan.

\section{SIMPULAN}

Setelah melakukan kajian di berbagai literatur dalam bahasan makalah di atas, kesimpulannya ialah:

1. Standar proses pembelajaran ialah acuan 
143 Kebijakan Standar Proses Di Sekolah Dasar - Lisa Syupriyanti, Sufyarma Marsidin, Ahmad Sabandi DOI: 10.31004/edukatif.v2i2.116

mengenai pelaksanan pembelajaran pada satuan pendidikan dasar dan menengah untuk mencapai kompetensi kelulusan

2. Karakteristik pembelajaran harus sesuai dengan tingkatan yang mempunyai standar tersendiri

3. Proses pembelajaran terbagi dalam beberapa aspek seperti:

a. Perencanan pembelajaran seperti menyusun silabus dan (RPP);

b. Pelaksanaan pembelajaran mulai dari kegiatan awal, inti dan akhir

c. Penilaian pembelajaran untuk menilai hasil belajar

Pengawasan (supervisi) proses pembelajaran ialah fungsi baru pada Permendikbud No 65 Tahun 2013.

\section{DAFTAR RUJUKAN}

Arifin, Z. (2012). Evaluasi Pembelajaran. Bandung: PT Remaja Rosdakarya.

Depdiknas. (2003). Undang-undang No. 20 Tahun 2003 tentang Sistem Pendidikan Nasional. Jakarta: Depdiknas.

Kemendikbud. (2013). Lampiran Peraturan Menteri Pendidikan \& Kebudayaan RI No. 65 Tahun 2013 tentang Standar Proses Pendidikan Dasar \& Menengah. Jakarta: Kemendikbud.

Kemendiknas. (2005). Peraturan Pemerintah No. 19 Tahun 2005 tentang Standar Nasional Pendidikan. Jakarta: Kemendikbud.

Majid, A. (2008). Perencanaan Pembelajaran. Bandung: PT Remaja Rosdakarya.

Muhcit, M. S. (2008). Pembelajaran Kontekstual. Semarang: Rasail Media Grup.

Purwanto, N. (2002). Prinsip-Prinsip dan Teknik Evaluasi Pengajaran. Bandung: PT Remaja Rosdakarya.
Sanjaya, W. (2008). Perencanaan dan Desain Sistem Pembelajaran. Jakarta: Kencana.

Sudjana, N. (2010). Penilaian Proses Belajar Mengajar. Bandung: PT Remaja Rosdakarya. 